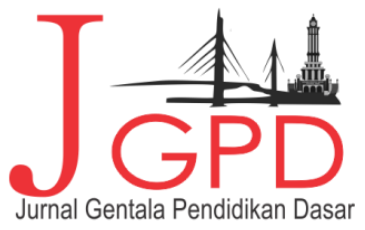

JURNAL GENTALA PENDIDIKAN DASAR Vol.3 No. I June 2018 Page 20-38

P-ISSN : 2614-7092, E-ISSN : 2621-9611

Available Online at: http://online-journal.unja.ac.id/index.php/gentala

email : penyunting.jurnal.g-pgsd国unja.ac.id

Research Article

\title{
Implementasi Pendidikan Karakter Mandiri Di Sekolah Dasar
}

\author{
Maryono $^{1}$, Hendra Budiono ${ }^{2}$, Resty Okha $^{3}$ \\ ${ }^{1,2,3)}$ PGSD FKIP Universitas Jambi, Jambi, Indonesia
}

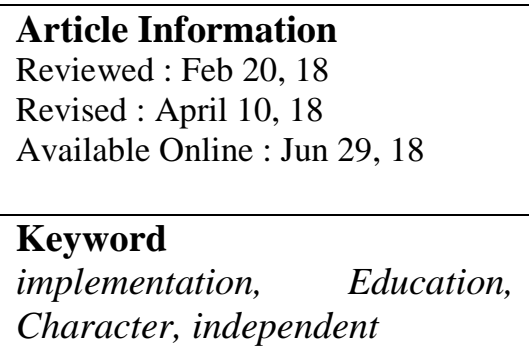

Corespondence

e-mail :

maryono@unja.ac.id
The purpose of this study is to describe the implementation of independent character education in the 2013 curriculum and to know the obstacles faced by teachers in implementing independent character education in the 2013 curriculum. The research method used in this study was qualitative with the research subject being 2 grade IV teachers at SDN. No. 112 / I Perumnas Muara Bulian. Based on the results of the research and discussion, the teacher as an educator in the school must be able to implement the value of independent character in the class by giving assignments to students so that students can do the tasks given by the teacher individually / independently. This is because there are still many students who rely on teachers and fellow students in the learning process.

DOI : https://doi.org/10.22437/gentala.v3i1.6750

\section{PENDAHULUAN}

Pendidikan juga merupakan suatu bentuk wujud nyata akan usaha manusia menjadi makhluk yang beradab. John S. Brubacher (dalam Siswoyo, 2008:18) menegaskan "bahwa pendidikan merupakan proses dalam mana potensi-potensi, kemampuan-kemampuan, kapasitaskapasitas manusia yang mudah dipengaruhi oleh kebiasaan-kebiasaan, disempurnakan dengan kebiasaan-kebiasaan yang baik, dengan alat (media) yang disusun sedemikian rupa, dan digunakan oleh manusia untuk menolong orang lain atau dirinya sendiri dalam pencapaian tujuan-tujuan yang ditetapkan."

Pendidikan mempunyai peran yang besar dalam pembentukan karakter bangsa Indonesia. Pendidikan tidak hanya mentransformasikan pengetahuan saja, tetapi juga mempunyai peran dalam membentuk karakter bangsa. Dengan kata lain pendidikan hendaknya membentuk insan yang cerdas dan berkarakter, sehingga akan menciptakan bangsa yang unggul dalam prestasi dan santun berinteraksi sesuai dengan nilai-nilai luhur bangsa. Hal ini juga dipertegas oleh Bung Karno (Samani dan Hariyanto, 2013:1) yang menyatakan bahwa "bangsa ini harus dibangun 


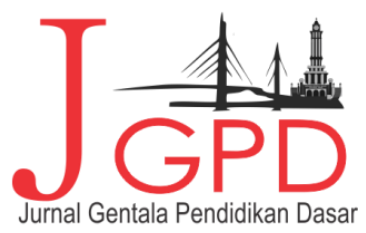

JURNAL GENTALA PENDIDIKAN DASAR Vol.3 No. I June 2018 Page 20-38

P-ISSN : 2614-7092, E-ISSN : 2621-9611

Available Online at: http://online-journal.unja.ac.id/index.php/gentala

email : penyunting.jurnal.g-pgsd国unja.ac.id

dengan mendahulukan pembangunan karakter (character building) karena character building inilah yang akan membuat Indonesia menjadi bangsa yang besar, maju dan jaya serta bermartabat. Kalau character building ini tidak dilakukan, maka bangsa Indonesia akan menjadi bangsa kuli. Senada dengan pernyataan Bung Karno tersebut, Forester (Wibowo, 2012:26) berpendapat bahwa tujuan pendidikan adalah untuk pembentukan karakter yang terwujud dalam kesatuan esensial subjek dengan perilaku dan sikap hidup yang dimilikinya. Ini berarti bahwa pendidikan karakter sangat penting dalam dunia pendidikan.

Pendidikan karakter harus berkelanjutan dan tak pernah berakhir (never ending process), sebagai bagian terpadu untuk menyiapkan generasi bangsa, yang disesuaikan dengan sosok manusia masa depan, berakar pada filosofi dan nilai kultural religius bangsa Indonesia. Pendidikan karakter harus menumbuh kembangkan filosofi dan pengamalan atas keseluruhan karakter bangsa ini secara utuh, dan menyuluruh. Karakter bangsa mengandung perekat budaya dan kultural yang harus terwujud dalam kesadaran kultural (cultural awareness) dan kesadaran kultural (cultural intelligence) setiap warga Negara. Penanaman karakter bangsa yang secara sistematis bisa dilakukan dengan baik salah satunya adalah melalui penambahan muatan dalam kurikulum sekolah. Apakah secara mandiri diwujudkan dalam mata pelajaran tersendiri ataukah melalui integrasi pesan penanaman karakter bangsa pada setiap mata pelajaran yang ada.

Sistem Pendidikan Nasional di Indonesia selalu berkembang dan berubah sesuai dengan perkembangan zaman. Perubahan yang dimaksud adalah pengembangan ke arah sistem pendidikan yang lebih baik. Kondisi yang ada saat ini dan antisipasi terhadap masa depan menuntut penyesuaian dan perubahan kurikulum. Perubahan kurikulum yang terjadi pada tahun 2013 menjadi bukti bahwa pemerintah Indonesia terus mengembangkan sistem pendidikan yang berkualitas. Di dalam kurikulum tersebut dirumuskan secara terpadu kompetensi sikap, pengetahuan, dan keterampilan yang harus dikuasai peserta didik. Selain itu, siswa tidak hanya diharapkan bertambah pengetahuan dan wawasannya, tetapi juga meningkat kecakapan dan keterampilannya serta semakin mulia karakter dan kepribadiannya atau yang berbudi pekerti luhur..

Proses pendidikan karakter dapat diibaratkan dalam sebuah kalimat bahwa apa yang ditanam sama seperti apa yang nanti diperoleh. Ibarat tersebut berarti bahwa pembentukan 


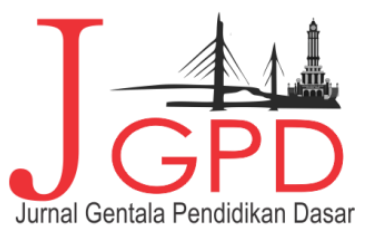

JURNAL GENTALA PENDIDIKAN DASAR Vol.3 No. I June 2018 Page 20-38

P-ISSN : 2614-7092, E-ISSN : 2621-9611

Available Online at: http://online-journal.unja.ac.id/index.php/gentala

email : penyunting.jurnal.g-pgsd国unja.ac.id

karakter anak ketika masih dalam tahap pembentukan kepribadian sangat berpengaruh terhadap kepribadiannya di masa depan. Salah satu bentuk pendidikan karakter yang perlu segera ditanamkan pada anak usia sekolah dasar adalah pendidikan karaketr mandiri. Anak usia sekolah dasar merupakan anak yang sedang berkembang dan merupakan masa yang tepat untuk menanamkan karakter mandiri yang baik. Menunjukkan kemampuan belajar secara mandiri sesuai dengan potensi yang dimilikinya, menunjukan kemampuan menganalisis dan memecahkan masalah dalam kehidupan sehari-hari, pantang menyerah, tanggungjawab, percaya diri, dan memanfaatkan waktu luang dengan baik adalah bentuk pendidikan karakter mandiri yang perlu tertanam pada diri anak di usia sekolah dasar. Wibowo (2012:7) berpendapat bahwa karakteristik psikologis siswa usia SD adalah masa-masa dominan dalam pembentukan karakter dan kepribadian. Jika pada masa ini penanaman karakter mandiri dengan secara sempurna, maka akan menjadi pondasi dasar dan kepribadian anak ketika dewasa kelak.

Nilai-nilai karakter mandiri merupakan upaya untuk membantu perkembangan jiwa anakanak baik lahir maupun batin, dari sifat kodratnya menuju ke arah peradaban yang manusiawi dan lebih baik. Sebagai contoh dapat dikemukakan misalnya anjuran atau suruhan terhadap anakanak untuk tidak tergantung pada orang lain dalam menyelesaikan berbagai tugas dan persoalan, namun hal ini bukan berarti tidak boleh bekerjasama secara kolaboratif melainkan tidak boleh melemparkan tugas dan tanggungjawab kepada orang lain, bertanggungjawab terhadap tugas yang diberikan guru, tidak berteriak-teriak agar tidak mengganggu orang lain. Pembentukan karakter merupakan salah satu tujuan pendidikan nasional. Pasal I UU sisdiknas tahun 2003 menyatakan bahwa diantara tujuan pendidikan nasional adalah mengembangkan potensi peserta didik untuk memiliki kecerdasan, kepribadian dan akhlak mulia.

Dari hasil pengamatan di lapangan saat penulis melakukan observasi ke Sekolah Dasar Negeri (SDN) 112/I Perumnas Muara Bulian ditemukan fakta bahwa SDN 112/I Perumnas Muara Bulian merupakan salah satu sekolah dasar yang menerapkan kurikulum 2013. Dalam wawancara dengan guru kelas IV A, dan IV B, menyatakan bahwa sekolah sudah menerapkan nilai-nilai karakter mandiri. Nilai-Nilai karakter mandiri menjadi salah satu hal yang utama dalam pembelajaran di kelas maupun di sekolah. Sehingga, siswa di sekolah tersebut diharapkan memiliki kebiasaan tidak tergantung kepada orang lain. Namun, guru merasa bahwa komunikasi 


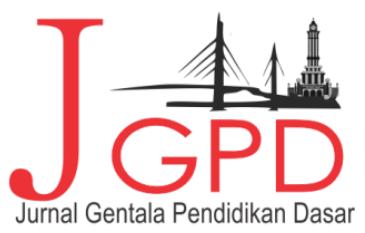

JURNAL GENTALA PENDIDIKAN DASAR Vol.3 No. I June 2018 Page 20-38

P-ISSN : 2614-7092, E-ISSN : 2621-9611

Available Online at: http://online-journal.unja.ac.id/index.php/gentala

email : penyunting.jurnal.g-pgsd国unja.ac.id

antara orang tua dengan pihak sekolah masih kurang, salah satunya tentang pendidikan karakter mandiri. Dan pada kenyataannya pada saat proses pembelajaran berlansung masih banyak siswa yang bergantung kepada sesama teman dan guru. Disini peneliti juga ingin mengetahui tentang hambatan guru dalam mengimplementasikan nilai-nilai pendidikan karakter mandiri.

Berdasarkan latar belakang penelitian di atas, maka penulis mencoba untuk melakukan penelitian dengan mengambil judul Implementasi Pendidikan Karakter Mandiri Dalam Kurikulum 2013 di Kelas IV SDN 112/I Perumnas Muara Bulian

Mengingat luasnya ruang lingkup permasalahan serta keterbatasan yang peneliti miliki, maka dalam penelitian ini peneliti melakukan fokus penelitian implementasi pendidikan karakter mandiri dalam kurikulum 2013 yaitu tema 7 (Cita-Citaku) dengan sub tema 1 (Aku dan CitaCitaku) di kelas IV SDN 112/I Perumnas Muara Bulian.

Berdasarkan fokus penelitian di atas, maka dalam penelitian ini sebagai rumusan masalah adalah:

Bagaimana implementasi pendidikan karakter mandiri dalam pembelajaran menggunakan kurikulum 2013 di kelas IV SDN 112/I Perumnas Muara Bulian?

Sesuai dengan rumusan masalah, maka sebagai tujuan dari penelitian ini adalah: Mendeskripsikan dan mengimplementasikan pendidikan karakter mandiri di kelas IV SDN 112/I Perumnas Muara Bulian.

\section{METODE PENELITIAN}

Jenis penelitian yang digunakan dalam penelitian ini adalah kualitatif yaitu penelitian yang dilakukan pada obyek alamiah. Obyek alamiah adalah obyek yang berkembang apa adanya, tidak dimanipulasi oleh peneliti dan kehadiran peneliti tidak begitu mempengaruhi dinamika pada obyek tersebut. Teknik pengumpulan data bersifat triangulasi, yaitu menggunakan berbagai teknik pengumpulan data secara gabungan atau simultan. Analisis data yang dilakukan bersifat induktif berdasarkan fakta-fakta yang ditemukan di lapangan.

Metode penelitian kualitatif digunakan untuk mendapatkan data yang mendalam, suatu data yang mengandung makna. Makna adalah data yang sebenarnya, data yang pasti yang merupakan suatu nilai di balik data yang tampak. Dalam penelitian ini mencari data tentang 


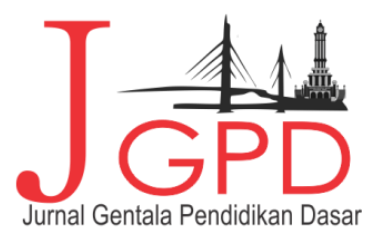

JURNAL GENTALA PENDIDIKAN DASAR Vol.3 No. I June 2018 Page 20-38

P-ISSN : 2614-7092, E-ISSN : 2621-9611

Available Online at: http://online-journal.unja.ac.id/index.php/gentala

email : penyunting.jurnal.g-pgsd回unja.ac.id

implementasi pendidikan karakter mandiri dalam kurikulum 2013 di SDN 112/1 Perumnas Muara Bulian.

\section{Tempat dan Waktu Penelitian}

\section{Tempat Penelitian}

Penelitian ini dilakukan di Kecamatan Muara Bulian Kabupaten Batanghari yang bertempat di SDN 112/1 Perumnas.

\section{Waktu Penelitian}

Peneliti melakukan penelitian di SDN No.112/I Perumnas Muara Bulian yang dilaksanakan pada semester genap tahun pelajaran 2015/2016.

\section{Subjek penelitian}

Menurut Mukhtar (2013:89) "subjek penelitian adalah orang yang berada dalam situasi sosial yang ditetapkan sebagai pemberi informasi dalam sebuah penelitian atau dikenal dengan informan". Informan dalam penelitian ini adalah guru kelas IV A dan guru kelas IV B SDN No.112/1 Perumnas Muara Bulian.

Tabel 1. Subjek Penelitian

\begin{tabular}{ccc}
\hline No & Nama & Jabatan \\
\hline 1. & Zulbaidah, S.Pd & Guru kelas IV A \\
\hline 2. & Rohana, S.Pd & Guru kelas IV B \\
\hline
\end{tabular}

\section{Data dan Sumber Data Penelitian}

Dalam penelitian ini adalah penelitian kualitatif . Menurut Lofland (dalam Moleong, 2010:157) bahwa "sumber data utama dalam penelitian kualitatif adalah kata-kata dan tindakan selebihnya adalah data tambahan seperti dokumentasi dan lain-lain. 


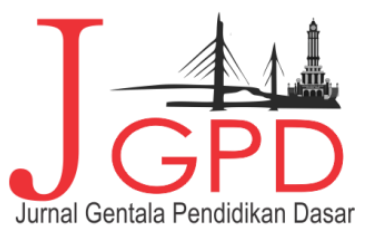

JURNAL GENTALA PENDIDIKAN DASAR Vol.3 No. I June 2018 Page 20-38

P-ISSN : 2614-7092, E-ISSN : 2621-9611

Available Online at: http://online-journal.unja.ac.id/index.php/gentala

email : penyunting.jurnal.g-pgsd国unja.ac.id

Menurut Buku panduan menulis skripsi (2011:33) "dalam penelitian kualitatif dapat berupa transkip wawancara, foto, naskah, dan lain-lain yang relevan”. Dengan demikian peneliti mengambil data dari wawancara, kegiatan observasi dan dokumentasi yang berhubungan dengan Pendidikan Karakter Mandiri.

"Data adalah segala fakta dan angka yang dapat dijadikan bahan untuk menyusun suatu informasi" (Arikunto, 2005:118) sedangkan sumber data menurut Arikunto (2013:172) "sumber data penelitian adalah subjek dari mana data dapat diperoleh".

Sumber data utama dalam penelitian kualitatif ialah kata-kata dan tindakan selebihnya adalah tambahan seperti dokumen dan lain-lain.

\section{Data Penelitian}

Data dalam penelitian ini bersifat deskriptif karena ingin menjelaskan implementasi pendidikan karakter dalam kurikulum 2013. Data dalam penelitian ini berupa transkrip wawancara dengan guru kelas, hasil observasi selama proses penelitian dan dokumentasi.

\section{Sumber Data Penelitian}

Dari pengertian tersebut, maka yang menjadi sumber data dalam penelitian ini adalah guru kelas IV di SDN No. 112/1 Perumnas Muara Bulian sebanyak 2 orang guru kelas IV A dan guru kelas IV B.

\section{Instrumen Penelitian}

Dalam penelitian kualitatif, yang menjadi instrumen atau alat penelitian adalah peneliti itu sendiri atau human instrument (Sugiyono, 2010:306). Berfungsi menetapkan fokus penelitian atau rumusan masalah, memilih informan sebagai sumber data, melakukan pengumpulan data, menilai kualitas data, analisis data, menafsirkan data dan membuat kesimpulan atas hasil penelitian. Dengan instrumen penelitian akan memudahkan dalam melakukan penelitian. Agar mendapatkan data yang baik dan akurat sesuai dengan tujuan penelitian ini, maka penelitian secara langsung meneliti Implementasi Pendidikan Karakter Mandiri dalam Kurikulum 2013 di kelas IV. 


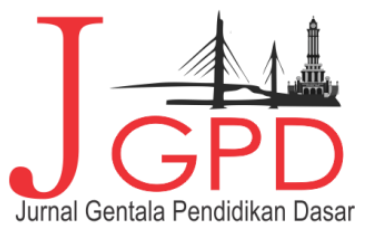

JURNAL GENTALA PENDIDIKAN DASAR Vol.3 No. I June 2018 Page 20-38

P-ISSN : 2614-7092, E-ISSN : 2621-9611

Available Online at: http://online-journal.unja.ac.id/index.php/gentala

email : penyunting.jurnal.g-pgsd回unja.ac.id

\section{Instrumen Pengumpulan Data}

Teknik pengumpulan data merupakan langkah yang paling utama dalam penelitian, karena tujuan utama dari penelitian adalah mendapatkan data (Sugiyono, 2010:308). Pengumpulan data dapat dilakukan dalam berbagai seting, berbagai sumber, dan berbagai cara. Dalam penelitian ini menggunakan 3 (tiga) teknik pengumpulan data :

\section{Observasi}

Observasi merupakan teknik pengumpulan data melalui pengamatan dan pencatatan yang dilakukan secara teliti dan sistematis atas fenomena yang sedang berlangsung. Dalam penelitian ini menggunakan observasi terus terang dan tersamar, peneliti dalam melakukan pengumpulan data menyatakan terus terang kepada sumber data, bahwa sedang melakukan penelitian. Jadi nara sumber yang diteliti mengetahui sejak awal sampai akhir tentang aktivitas peneliti. Tetapi dalam suatu saat peneliti juga tidak terus terang atau tersamar dalam observasi, hal ini untuk menghindari kalau suatu data yang dicari merupakan data yang masih dirahasiakan (Sugiyono, 2010:312). Peneliti dalam mengumpulkan data ikut observasi partisipatif dalam beberapa kegiatan saja.

Kegiatan pengamatan dilakukan selama peneliti melakukan penelitian di SDN 112/1 Perumnas Muara Bulian. Pengamatan terhadap kegiatan pembelajaran kurikulum 2013 dilakukan di kelas IV untuk mengetahui secara mendalam tentang implementasi nilai-nilai karakter mandiri dalam pembelajaran. Dalam penelitian, guna lebih memudahkan peneliti dalam melakukan kegiatan pencatatan atas hasil pengamatan, maka peneliti menyiapkan pedoman observasi sebagaimana berikut.

Tabel 2. Pedoman Observasi

\begin{tabular}{ccc} 
No & Pendidikan Karakter Mandiri & Deskrispsi Hasil Temuan \\
\hline 1 & Percaya diri
\end{tabular}




\begin{tabular}{l} 
Available Dnline at: http://online-journal.unja.ac.id/index.php/gentala \\
email : penyunting.jurnal.g-pgsd国unja.ac.id \\
\hline 3 Kemampuan belajar sendiri \\
\hline 4 Kemampuan menganalisis dan memecahkan masalah \\
Bertanggung jawab
\end{tabular}

\section{Wawancara}

Wawancara digunakan sebagai teknik pengumpulan data apabila penelitian ingin mengetahui hal-hal dari nara sumber yang lebih mendalam. Dengan wawancara, maka peneliti akan mengetahui hal-hal yang lebih mendalam tentang nara sumber dalam menginterprestasikan situasi dan fenomena yang terjadi, dimana hal ini tidak bisa ditemukan melalui observasi.

Dalam penelitian ini menggunakan wawancara terstruktur sebagai teknik pengumpulan data. Wawancara terstruktur, adalah wawancara yang bebas dimana peneliti menggunakan pedoman wawancara yang telah tersusun secara sistematis dan lengkap untuk pengumpulan datanya. Secara garis besar wawancara akan dilakukan terhadap guru kelas IV SDN 112/1 Perumas Muara Bulian sebagai nara sumber adalah tentang implementasi pendidikan karakter

Mandiri dalam kurikulum 2013 serta hambatan yang dialami pada implementasinya. Pedoman wawancara dengan guru kelas IV SDN 112/I Perumnas Muara Bulian adalah sebagaimana tabel berikut:

Tabel 3. Pedoman Wawancara Dengan Guru kelas IV A dan IV B

\begin{tabular}{lc}
\hline Informan & Pertanyaan \\
\hline Guru kelas IV & 1. Bagaimana pendapat ibu tentang tujuan pendidikan karakter \\
& mandiri di SDN No. 112/1? \\
2. Bagaimana ibu menerapkan pendidikan karakter mandiri dalam & pembelajaran? \\
3. Apakah metode pembelajaran yang ibu kembangkan dalam \\
menanamkan karakter mandiri pada siswa? \\
4. Bagaimana wujud percaya diri, kemampuan belajar sendiri, \\
kemampuan menganalisa dan memecahkan masalah, bertanggung \\
jawab, dan pantang menyerah, yang ditunjukkan siswa di dalam \\
kelas? \\
5. Apa kendala yang ibu hadapi dalam menerapkan pendidikan \\
karakter pada siswa?
\end{tabular}




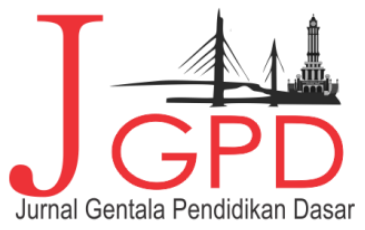

JURNAL GENTALA PENDIDIKAN DASAR Vol.3 No. I June 2018 Page 20-38

P-ISSN : 2614-7092, E-ISSN : 2621-9611

Available Online at: http://online-journal.unja.ac.id/index.php/gentala

email : penyunting.jurnal.g-pgsd国unja.ac.id

Dokumentasi

Dokumentasi adalah untuk mencari data mengenai hal-hal atau variabel yang berupa catatan, transkrip, buku, surat kabar, majalah, prasasti, natulen, rapat, agenda dan sebagainya (Arikunto, 2010:201).

Dalam penelitian ini untuk mendukung data yang diperoleh dari hasil observasi dan wawancara yang telah dilakukan, kemudian data-data yang berkaitan dengan implementasi pendidikan karakter mandiri dalam kurikulum 2013, kemudian data lainnya diperoleh peneliti dari hasil dokumentasi berupa foto dan lain-lain yang mendukung pelengkapan data penelitian.

\section{Teknik Analisis Data}

Analisis data dalam penelitian kualitatif, dilakukan pada saat pengumpulan data berlangsung, dan setelah selesai pengumpulan data dalam priode tertentu. Pada saat wawancara, peneliti sudah melakukan analisis terhadap jawaban yang di wawancarai. Bila jawaban yang di analisis terasa belum menyenangkan, maka peneliti melanjutkan dengan pertanyaan lagi.

Analisis data kualitatif dilakukan secara interaktif dan berlangsung secara terus menerus sampai tuntas, sehingga data jenuh. Ukuran kejenuhan data ditandai dengan tidak diperolehnya lagi data atau informasi baru. Aktivitas analisis dalam penelitian ini menggunakan analisis data lapangan model Miles and Hubeman yang meliputi reduksi data (data reduction), penyajian data (data display) serta penarikan kesimpulan dan verifikasi (conclusion drawing/verification).

Tahap Reduksi Data

Mereduksi data berarti merangkum, memilih hal yang pokok, memfokuskan pada hal-hal yang penting, dicari tema dan rencananya. Dengan demikian data yang telah direduksi akan memberikan gambaran yang lebih jelas, dan mempermudah peneliti untuk melakukan pengumpulan data selanjutnya, dan mencari bila diperlukan. Peneliti memfokuskan terhadap implementasi pendidikan karakter mandiri dalam kurikulum 2013.

Tahap Penyajian Data/ Analisis Data Setelah Pengumpulan Data 


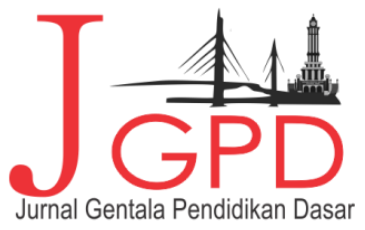

JURNAL GENTALA PENDIDIKAN DASAR Vol.3 No. I June 2018 Page 20-38

P-ISSN : 2614-7092, E-ISSN : 2621-9611

Available Online at: http://online-journal.unja.ac.id/index.php/gentala

email : penyunting.jurnal.g-pgsd国unja.ac.id

Setelah data direduksi, maka langkah selanjutnya adalah penyajian data (data display). Penyajian data dalam penelitian ini dilakukan dalam bentuk uraian singkat, dengan teks yang bersifat naratif. Langkah-langkah yang dilakukan pada tahap ini adalah:

a. Mengumpulkan dan menyusun data hasil reduksi menjadi data yang relevan dan berurutan sehingga menghasilkan informasi yang dapat disimpulkan.

b. Setelah data yang relevan dan berurutan tersusun, kemudian dilakukan analisis secara mendalam untuk menemukan hubungan interaktif diantara data tersebut.

c. Langkah terakhir dalam tahap ini adalah menyajikan data yang telah terkumpul dan dianalisis kedalam pola atau format sistematis yang mudah untuk dibaca dan dipahami baik oleh peneliti maupun orang lain.

Tahap Penarikan Kesimpulan dan Verifikasi

Langkah selanjutnya adalah tahap penemuan dan penarikan kesimpulan berdasarkan temuan dan melakukan verifikasi data. Seperti yang dijelaskan diatas bahwa kesimpulan awal yang dikemukakan masih bersifat sementara dan akan berubah bila ditemukan bukti-bukti kuat yang mendukung tahap pengumpulan data berikutnya. Proses untuk mendapatkan bukti-bukti inilah yang disebut sebagai verifikasi data. Apabila kesimpulan yang dikemukakan pada tahap awal didukung oleh bukti-bukti yang kuat dalam arti konsisten dengan kondisi yang ditemukan saat peneliti kembali ke lapangan maka kesimpulan yang diperoleh merupakan kesimpulan yang kredibel.

\section{Uji Keabsahan Data}

Sebagai teknik pengujian keabsahan data dalam penelitian ini peneliti menggunakan teknik triangulasi. Triangulasi adalah tekhnik pemeriksaan keabsahan data yang memanfaatkan suatu yang lain diluar dari data yang dimiliki peneliti untuk keperluan pengecekan atau sebagai perbandingan terhadap data tersebut.

Dalam penelitian ini penulis menggunakan Triangulasi dengan sumber yang membandingkan dan mengecek balik derajat kepercayaan suatu informasi yang diperoleh melalui observasi, wawancara, dan dokumentasi. Hal ini dapat dicapai dengan membandingkan data hasil pengamatan dengan data hasil wawancara, membandingkan dengan apa yang dikatakan orang 


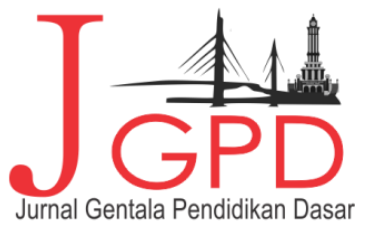

JURNAL GENTALA PENDIDIKAN DASAR Vol.3 No. I June 2018 Page 20-38

P-ISSN : 2614-7092, E-ISSN : 2621-9611

Available Online at: http://online-journal.unja.ac.id/index.php/gentala

email : penyunting.jurnal.g-pgsd回unja.ac.id

didepan umum dengan apa yang dikatakan pribadi, apa yang dikatakan orang dengan situasi penelitian dengan apa yang dikatakan orang sepanjang waktu, membandingkan keadaan dan perspektif dengan keadaan lain.

Berdasarkan tekhnik triangulasi tersebut diatas, maka dimaksud untuk mengecek kebenaran data keabsaahan data-data yang diperoleh dilapangan tentang implementasi pendidikan karakter mandiri pada kurikulum 2013 di SDN 112/1 Perumnas Muara Bulian yang bersumber dari observasi, wawancara maupun dokumentasi, sehingga dapat dipertanggung jawabkan seluruh data yang diperoleh dilapangan dalam penelitian tersebut.

\section{Tahap-tahap Penelitian}

Adapun tahap-tahap yang dilakukan oleh peneliti dalam pelaksanaan penelitian adalah sebagai berikut.

\section{Tahap Persiapan}

1) Menyusun Instrumen Penelitian

Penyusunan instrument penelitian ini disusun berdasarkan tujuan penelitian dan jenis data yang di jadikan sumber penelitian, instrument yang digunakan dalam mengumpulkan data adalah observasi, wawancara dan dokumentasi.

2) Mendatangi Informan

Agar dalam pelaksanaan penelitian tidak terjadi kesalahpahaman bagi responden, maka penelitian perlu mendatangi informan untuk memberi informasi seperlunya kepada responden.

2. Tahap Pelaksanaan Penelitian

Kegiatan yang dilakukan pada tahap ini adalah mengumpulkan data dengan instrumen-instrumen yang sudah di persiapkan, mengelola data, menganalisis data, dan menyimpulkan data. Dalam kegiatan ini peneliti membawa surat izin dari Fakultas Keguruan dan Ilmu Pendidikan Universitas Jambi untuk mengambil data di lapangan.

\section{Tahap Penyelesaian}

Kegiatan yang dilakukan dalam tahap ini adalah menyusun data-data yang telah di peroleh dan analisis dalam bentuk laporan hasil penelitian yang di tempatkan pada BAB IV dan BAB V. 


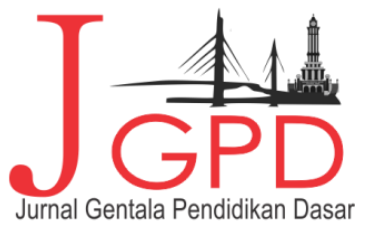

JURNAL GENTALA PENDIDIKAN DASAR Vol.3 No. I June 2018 Page 20-38

P-ISSN : 2614-7092, E-ISSN : 2621-9611

Available Online at: http://online-journal.unja.ac.id/index.php/gentala

email : penyunting.jurnal.g-pgsd回unja.ac.id

\section{HASIL DAN PEMBAHASAN}

\section{Hasil}

Penelitian ini mengenai implementasi pendidikan karakter mandiri dalam kurikulum 2013 di kelas IV SDN 112/1 Perumnas Muara Bulian Kabupaten Batanghari dengan subjek penelitian 2 orang yaitu guru kelas IV A bernama Ibu Zulbaidah dan guru kelas IV B bernama Ibu Rohana. Sebelum peneliti melaksanakan penelitian di sekolah ini terlebih dahulu peneliti meminta izin kepada pihak sekolah yaitu kepala sekolah SDN 112/1 Perumnas. Pada tanggal 25 Januari 2016 peneliti datang kesekolah untuk meminta izin kepada Kepala Sekolah yang bernama Ibu Asni Mulyati dan diberikan izin untuk melakukan penelitian di sekolah tersebut. Setelah mendapat izin peneliti langsung terjun kelapangan untuk melakukan observasi dan bertemu dengan guru kelas IV yang akan dijadikan narasumber saat penelitian berlangsung. Setelah selesai melakukan observasi peneliti melakukan wawancara kepada narasumber. Adapun hasil penelitian sebagai berikut.

\section{Hasil Observasi}

Berdasarkan hasil observasi secara langsung yang telah dilakukan oleh peneliti tentang pendidikan karakter mandiri pada tema 7 (cita-citaku) pembelajaan 1 (aku dan cita-citaku) yang telah dilaksanakan oleh guru kelas IV pada saat proses pembelajaran berlangsung. Peneliti berada dibelakang agar siswa tidak merasa terganggu dalam pembelajarannya. Adapun hasil observasi nya sebagai berikut :

Percaya Diri, berdasarkan hasil observasi yang dilakukan oleh peneliti bahwa guru dalam menanamkan rasa percaya diri pada peserta didik pada saat akan memulai pembelajaran apersepsi sambil memotivasi siswa. Dengan memberikan pertanyaan-pertanyaan dan mengadakan diskusi singkat tentang hal-hal apa saja yang telah diketahui siswa, tidak hanya menjadikan pembelajaran lebih mudah dipahami tetapi juga akan membuat peserta didik percaya diri menyampaikan pendapatnya. 


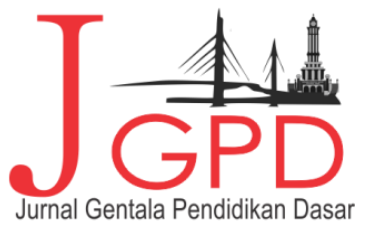

JURNAL GENTALA PENDIDIKAN DASAR Vol.3 No. I June 2018 Page 20-38

P-ISSN : 2614-7092, E-ISSN : 2621-9611

Available Online at: http://online-journal.unja.ac.id/index.php/gentala

email : penyunting.jurnal.g-pgsd回unja.ac.id

Kemampuan belajar sendiri, berdasarkan hasil observasi yang dilakukan oleh peneliti bahwa guru dalam menanamkam kemampuan belajar sendiri pada peserta didik dengan cara guru memberikan tugas, seperti membuat puisi dengan tema cita-citaku, bahwa tidak semua peserta didik memiliki kemampuan belajar sendiri.

Kemampuan menganalisis dan memecahkan masalah, berdasarkan hasil observasi yang dilakukan oleh peneliti bahwa guru dalam menanamkan kemampuan menganalisis dan memecahkan masalah pada peserta didik dengan cara guru memperhatikan kondisi dan perkembangan kesehatan fisik dan mental peserta didik, membantu pengembangan sifat-sifat positif pada diri peserta didik seperti rasa percaya diri pada peserta didik dan saling menghormati, menciptakan kesempatan belajar lebih baik bagi peserta didik dan memberikan ransangan belajar sebanyak mungkin.

Bertanggung jawab, berdasarkan hasil observasi yang dilakukan oleh peneliti bahwa guru dalam menanamkam rasa tanggung jawab peserta didik dengan cara guru memberikan tugas individu kepada peserta didik, sebagian ada peserta didik yang dengan cepat menyelesaikan tugas tersebut, ada juga peserta didik yang tidak selesai membuat tugas yang diberikan oleh guru. Guru juga harus melihat apakah anak melakukannya dengan segenap hati dan tekun. Sangat penting bagi guru untuk memberikan suatu perhatian pada tugas yang sedang di kerjakan peserta didik. Jangan lah sekali-kali guru menunjukan secara langsung tentang kesalahan-kesalahan peserta didik, tetapi nyatakanlah bagaimana cara memperbaiki kesalahan tersebut.

\section{Hasil Wawancara}

Berdasarkan hasil wawancara pada tanggal 1 Februari 2016 ibu Zulbaidah selaku guru kelas IV A, berpendapat mengenai tujuan Pendidikan Karakter Mandiri di Sekolah yaitu:

" Guru harus lebih bisa mengembangkan potensi yang dimiliki oleh peserta didik agar peserta didik lebih mandiri dalam proses pembelajaran ".

Berdasarkan hasil wawancara pada tanggal 1 Februari 2016 ibu Zulbaidah selaku guru kelas IV A, mengenai cara guru dalam mengimplementasikan karakter mandiri dalam kurikulum 2013 menerangkan bahwa: 


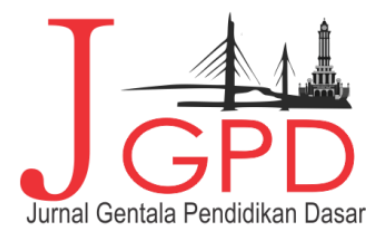

JURNAL GENTALA PENDIDIKAN DASAR Vol.3 No. I June 2018 Page 20-38

P-ISSN : 2614-7092, E-ISSN : 2621-9611

Available Online at: http://online-journal.unja.ac.id/index.php/gentala

email : penyunting.jurnal.g-pgsd国unja.ac.id

“ cara guru dalam mengimplementasikan pendidikan karakter mandiri adalah memacu siswa supaya tidak terlalu bergantung pada guru. Siswa harus bisa menalar dan siswa harus memiliki sikap percaya diri, pantang menyerah, dan terhindar dari ketergantungan pada orang lain ".

Berdasarkan hasil wawancara pada tanggal 1 Februari 2016 ibu Zulbaidah selaku guru kelas IV A, Apa metode pembelajaran yang ibu kembangkan dalam menanamkan Karakter Mandiri pada siswa

"Metode yang guru kembangkan dalam menanamkan karakter mandiri ini dengan menggunakan metode ceramah dan memberi penugasan pada peserta didik ".

Berdasarkan hasil wawancara pada tanggal 1 Februari 2016 ibu Zulbaidah selaku guru kelas IV A, Bagaimana wujud percaya diri, kemampuan belajar sendiri, kemampuan menganalisa dan memecahkan masalah, bertanggung jawab, dan pantang menyerah, yang di tunjukan siswa di dalam kelas?

“Dalam mewujudkan rasa percaya diri peserta didik, guru melatih siswa untuk bertanya jawab ketika proses pembelajaran, dalam proses pembelajaran ini guru bisa mengukur kemampuan siswa dalam menganalisa dan memecahkan masalah pada proses pembelajaran. Dalam proses pembelajaran ini siswa dituntut untuk bertanggung jawab untuk menyelesaikan tugas yang diberikan guru “.

Berdasarkan hasil wawancara pada tanggal 1 Februari 2016 ibu Zulbaidah selaku guru kelas IV A, kendala apa yang ibu hadapi dalam menerapkan Pendidikan Karakter Mandiri pada siswa ?

"Kendala yang guru hadapi dalam penerapan pendidikan karaker mandiri ini masih banyak siswa yang bergantung pada guru dan sesama teman, siswa masih banyak yang belum bisa bertanggung jawab terhadap tugasnya “.

Berdasarkan hasil wawancara pada tanggal 9 Februari 2016 ibu Rohana selaku guru kelas IV A, berpendapat mengenai tujuan Pendidikan Karakter Mandiri di Sekolah yaitu: 


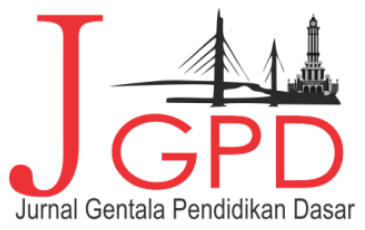

JURNAL GENTALA PENDIDIKAN DASAR Vol.3 No. I June 2018 Page 20-38

P-ISSN : 2614-7092, E-ISSN : 2621-9611

Available Online at: http://online-journal.unja.ac.id/index.php/gentala

email : penyunting.jurnal.g-pgsd国unja.ac.id

“Mengembangkan potensi peserta didik dalam proses pembelajaran. Meningkatkan mutu penyelenggaraan dan hasil pendidikan di sekolah yang mengarah pada pencapaian pembentukan karakter. Penanaman nilai-nilai pendidikan kemandirian dalam diri siswa dan pembaharuan tata kehidupan bersama yang lebih menghargai kebebasan individu. Misalnya setiap hari peserta didik guru ajarkan belajar bertanggung jawab untuk melaksanakan tanpa dibantu oleh guru, seperti tugas sehari-hari peserta didik dengan menyiram kembang setiap pagi, itu salah satu karakter mandiri. Membuat Pekerjaan Rumah (PR) tanpa dibantu orang tua, peserta didik bisa mengerjakan PR itu dengan sendiri “.

Berdasarkan hasil wawancara pada tanggal 9 Februari 2016 ibu Rohana selaku guru kelas IV B, mengenai cara guru dalam mengimplementasikan karakter mandiri dalam kurikulum 2013 menerangkan bahwa:

“Cara guru dalam mengimplementasikan pendidikan karakter adalah mengerjakan tugas yang kita berikan secara individu, seperti pada Tema 7 Pembelajaran I tentang Cita-citaku. Pada pembelajaran ini guru memberikan tugas kepada peserta didik untuk membuat puisi tentang cita-cita mereka, setiap peserta didik harus memiliki cita-cita sesuai dengan keinginan mereka. Setiap peserta didik boleh mempunyai cita-cita yang sama tetapi isi puisi tidak boleh sama. Tujuan guru dalam memberikan tugas merangkai puisi ini agar peserta didik dapat mengungkapkan imajinasi mereka ".

Berdasarkan hasil wawancara pada tanggal 9 Februari 2016 ibu Rohana selaku guru kelas IV B, Apa metode pembelajaran yang ibu kembangkan dalam menanamkan Karakter Mandiri pada siswa

"Metode yang digunakan guru ialah metode ceramah dan penugasan, setelah itu guru memberikan tugas kepada peserta didik, apakah peserta didik itu mengerjakan tugas yang diberikan guru atau tidak, guru akan tau mana peserta didik yang belum selesai mengerjakannya. Guru bisa membimbing kesulitan peserta didik untuk mengerjakan tugas tersebut,kendala apa yang dihadapi peserta didik sehingga peserta didik itu tidak bisa mengerjakan tugas yang diberikan guru pasti ada kendalanya. Peserta didik banyak masih 


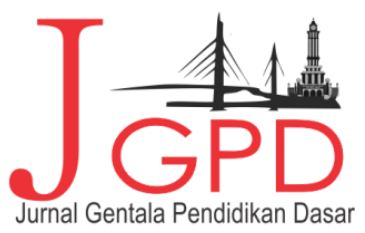

JURNAL GENTALA PENDIDIKAN DASAR Vol.3 No. I June 2018 Page 20-38

P-ISSN : 2614-7092, E-ISSN : 2621-9611

Available Online at: http://online-journal.unja.ac.id/index.php/gentala

email : penyunting.jurnal.g-pgsd国unja.ac.id

banyak daya ingat yang agak sedikit lemah. Guru harus mengulangi pembelajaran lagi supaya peserta didik bisa mengerti “.

Berdasarkan hasil wawancara pada tanggal 9 Februari 2016 ibu Rohana selaku guru kelas IV B, Bagaimana wujud percaya diri,kemampuan belajar sendiri, kemampuan menganalisa dan memecahkan masalah, bertanggung jawab, dan pantang menyerah, yang di tunjukan siswa di dalam kelas?

“ Dalam mewujudkan rasa percaya diri peserta didik, guru melatih siswa untuk bertanya jawab ketika proses pembelajaran, dalam proses pembelajaran ini guru bisa mengukur kemampuan siswa dalam menganalisa dan memecahkan masalah pada proses pembelajaran. Misalnya seperti yang di pelajari peserta didik tadi, belajar tentang menciptakan puisi dari apa yang di cita-citakan peserta didik, setelah peserta didik selesai mengerjakan tugas puisi yang diberikan guru, guru akan memeriksa puisi tersebut. Kemudian peserta didik membaca puisi tersebut didepan kelas ".

Berdasarkan hasil wawancara pada tanggal 9 Februari 2016 ibu Rohana selaku guru kelas IV B, kendala apa yang ibu hadapi dalam menerapkan Pendidikan Karakter Mandiri pada siswa ?

“ Kendala yang dihadapi guru ialah guru merasa bahwa komunikasi antara orang tua dengan pihak sekolah masih kurang, salah satunya tentang pendidikan karakter mandiri. Misalnya guru memberikan Pekerjaan Rumah (PR) kepada peserta didik, itu kan sudah tugasnya antara orang tua dengan peserta didik, terkadang peserta didik tidak mengerjakan PR tersebut, berarti orang tua tidak mengawasi peserta didik belajar dirumah. Guru disekolah sudah berusaha semaxsimal mungkin untuk mengajarkan siswa mandiri, sementara dirumah orang tua sibuk dengan pekerjaan masing-masing. Jadi itulah salah satu kendala guru dengan orang tua peserta didik. Memang tidak semua peserta didik yang tidak mengerjakan PR ada beberapa pesrta didik “.

\section{Temuan Penelitian}

Penelitian ini dilaksanakan oleh peneliti di kelas IV SDN No. 112/1 Perumnas Muara Bulian dengan melaksanakan pengamatan atau observasi secara langsung mengenai 


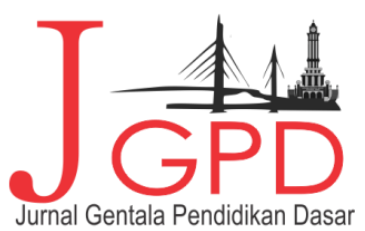

JURNAL GENTALA PENDIDIKAN DASAR Vol.3 No. I June 2018 Page 20-38

P-ISSN : 2614-7092, E-ISSN : 2621-9611

Available Online at: http://online-journal.unja.ac.id/index.php/gentala

email : penyunting.jurnal.g-pgsd国unja.ac.id

implementasi pendidikan karakter mandiri dalam kurikulum 2013 yang diterapkan oleh guru kepada siswa pada pembelajaran yang berlangsung. Setelah melakukan pengamatan peneliti juga melakukan wawancara kepada guru kelas mengenai implementasi pendidikan karakter mandiri dalam kurikulum 2013

Dari hasil observasi, wawancara dan dokumentasi yang telah peneliti lakukan maka dapat ditemukan penelitian sebagai berikut:

1. Guru mengalami kesulitan dalam melaksanakan pendidikan karakter mandiri dalam pembelajaran kurikulum 2013 dikelas, dikarenakan masih ada peserta didik yang belum bisa mengerjakan tugas secara individu/mandiri, peserta didik masih bergantung kepada guru dan sesama teman kelas, dan dirumah pun peserta didik masih masih berantung kepada orang tua dalam mengerjakan pekerjaan rumah (PR).

\section{Pembahasan}

Salah satu tujuan pendidikan di SDN 112/1 Perumnas Muara Bulian adalah untuk menerapkan nilai pendidikan karakter mandiri dalam kurikulum 2013. Guru sebagai tenaga pendidik di SDN 112/1 Perumnas Muara Bulian harus bisa mengimplementasikan nilai karakter mandiri di kelas dengan memberikan tugas kepada siswa agar peserta didik bisa mengerjakan tugas yang di berikan guru secara individu. Hal ini disebabkan karena masih banyak peserta didik yang mengandalkan guru dan sesama teman dalam proses pembelajaran. Guru harus berusaha untuk membantu siswa agar siswa lebih mandiri dalam proses pembelajaran.

Banyak usaha yang telah dilakukan pemerintah untuk mencerdaskan aspek emosional anak, salah satunya adalah dengan penanaman nilai-nilai karakter di sekolah dasar. Salah satu nilai karakter yang ditanamkan di sekolah dasar adalah karakter mandiri. Dengan adanya nilai karakter mandiri dalam dunia pendidikan bertujuan agar siswa mempunyai pengetahuan dan kesadaran bahwa setiap individu mempunyai peran dengan lingkungan di sekitarnya dan dapat menciptakan perubahan.

Berdasarkan paparan hasil wawancara terhadap ibu Zulbaidah dan Rohana dapat peneliti simpulkan bahwa guru dalam mengimplementasikan pendidikan karakter mandiri dalam 


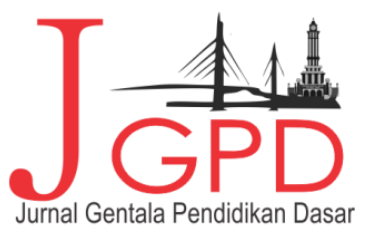

JURNAL GENTALA PENDIDIKAN DASAR Vol.3 No. I June 2018 Page 20-38

P-ISSN : 2614-7092, E-ISSN : 2621-9611

Available Online at: http://online-journal.unja.ac.id/index.php/gentala

email : penyunting.jurnal.g-pgsd回unja.ac.id

kurikulum 2013 di kelas adalah dengan cara memberikan tugas secara individu kepada peserta didik. Sarana dan prasarana pun menjadi bagian yang penting dalam pelaksanaan penerapan nilai pendidikan karakter mandiri agar dapat berjalan secara efektif, efisien, dan nyaman. Nilai karakter mandiri tersebut dapat dikembangkan melalui beberapa program yang dibentuk secara khusus untuk melatih dan membiasakan siswa untuk tidak bergantung pada guru dan sesama temannya

\section{KESIMPULAN DAN IMPLIKASI}

\section{Kesimpulan}

Simpulan dari penelitian implementasi pendidikan karakter mandiri dalam kurikulum 2013 di kelas IV SDN No. 112/1 Perumnas Muara Bulian yaitu : guru masih mengalami kesulitan dalam menerapkan pendidikan karakter mandiri dalam pembelajaran kurikulum 2013, dikarenakan masih ada peserta didik yang belum bisa mengerjakan tugas secara individu/mandiri, peserta didik masih bergantung kepada guru dan sesama teman kelas, dan dirumah pun peserta didik masih masih berantung kepada orang tua dalam mengerjakan pekerjaan rumah (PR).

\section{Implikasi}

Berdasarkan hasil penelitian ini, maka peneliti menyarankan kepada guru untuk meningkatkan pendidikan karakter mandiri di kelas. Selain itu, peneliti juga menyarankan kepada peneliti lain untuk bisa mengkaji dan meneliti ulang masalah ini, sebab hasil penelitian ini masih jauh dari kesempurnaan. Hal ini dikarenakan keterbatasan pengetahuan dan metodologi penulis, namun demikian semoga hasil penelitian ini bisa dijadikan acuan untuk penelitian selanjutnya.

\section{UCAPAN TERIMAKASIH}

Dalam kesempatan ini disampaikan penghargaan dan rasa terima kasih yang setulustulusnya kepada keluaraga besar SDN. No. 112/ I Perumnas Muara Bulian, Bapak/ Ibu pengelola 


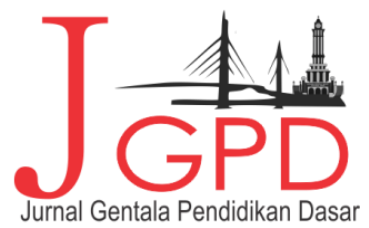

JURNAL GENTALA PENDIDIKAN DASAR Vol.3 No. I June 2018 Page 20-38

P-ISSN : 2614-7092, E-ISSN : 2621-9611

Available Online at: http://online-journal.unja.ac.id/index.php/gentala

email : penyunting.jurnal.g-pgsd国unja.ac.id

Jurnal Gentala Pendidikan Dasar PGSD FKIP Universitas Jambi atas kerjasamanya sehingga karya ilmiah ini dapat diterbitkan.

\section{DAFTAR PUSTAKA}

Arikunto, S. 2005. Prosedur Penelitian.Jakarta:Rineka Cipta.

Arikunto. 2010:2011. Prosedur Penelitian Suatu Pendekatan Praktik. Jakarta: Rineka Cipta

Asmani, Ma'mur Jamal. 2011. Buku Panduan Internalisasi Pendidikan karakter di Sekolah. Yogyakarta: Diva Press

Daryanto dan Darmiyantun Suryatri . 2013. Implementasi Pendidikan Karakter di Sekolah. Yogyakarta: Gava Media.

Fakultas Keguruan dan Ilmu Pendidikan Universitas Jambi. 2009. Buku Panduan Penulisan Proposal dan Skripsi Hasil Penelitian Tindakan Kelas (PTK). Jambi: Kementerian Pendidikan Nasional.

Ilahi, Takdir Muhammad. 2012. Revitalisasi Pendidikan Berbasis Moral. Yogyakarta: Ar-Ruzz Media

Koesoema, Doni A. 2007. Pendidikan Karakter. Jakarta: Grasindo

Muslich, Mansur. 2011. Pendidikan karakter: Menjawab Tantangan Krisis Multidimensional. Jakarta Bumi Aksara

Mulyasa, E. 2011. Manajemen Pendidikan Karakter. Jakarta: Bumi Aksara

Mustakim, Bagus. 2011. Pendidikan Karakter: Membangun Delapan Karakter Emas Indonesia Menuju Indonesia Bermartabat. Yogyakarta: Samudra Biru

Moleong. 2010. Metodologi Penelitian Kualitatif. Bandung : PT Remaja Pos dakarya

Mukhtar. 2013. Metode praktis Penelitian Deskriptif Kualitatif. Jakarta: Gaung Persada

Sugiyono. 2010. Metode Penelitian Pendidikan (Pendekatan Kuantitatif, Kualitatif, $R \& D$ ). Bandung: Alfabeta

Sugiyono. 2013. Metode Penelitian Kuantitaif dan kualitatif dan $R \& D$. Bandung: Alfabeta.

Wibowo, Agus. 2013. Menajemen Pendidikan Karakter di Sekolah. Yogyakarta: Pustaka Pelajar.

Wiyani, N. A.2013. Membumikan Pendidikan Karakter di Sekolah Dasar. Jogyakarta : Ar-Ruzz Media

Zubaedi. 2011. Desain Pendidikan Karakter: Konsep dan Aplikasinya dalam Lembaga Pendidikan. Jakarta: Kencana 